\title{
TIPOLOGI FASAD RUMAH ADAT BATAK TOBA
}

\author{
Koriana M. Sihotang ${ }^{(1)}$, Polin DR Naibaho, ST., MT ${ }^{(2)}$, Emmy Ria Aritonang, ST.,MT ${ }^{(3)}$ \\ (1) Mahasiswa, prodi arsitektur, fakultas teknik, universitas katolik santo thomas sumatera utara \\ (2) Staff pengajar, prodi arsitektur, fakultas teknik, universitas katolik santo thomas sumatera utara \\ Email : polin_naibaho@ust.ac.id \\ (3) Staff pengajar, prodi arsitektur, fakultas teknik, universitas katolik santo thomas sumatera utara \\ Email : emmyria1@gmail.com
}

\begin{abstract}
Batak Toba's traditional houses is one of the relics of batak tribe tradition that up to now still many abandon the values of philosophy and beauty and create a natural picture that is considered to have soul. Batak traditional house is a building that characterizes the house or typical of the tribe of Batak which symbolizes the culture and characteristics of the Batak community. Discussion in this research about typology facade of traditional Batak Toba house building in Tomok Village, Huta Bolon and Huta Siallagan. Facade typology discussed in this research is the front view, the use of materials, dimensions, the use of color, the placement of doors and windows of traditional houses of Batak Toba in Samosir. The research method used in this research is qualitative, that is describing the existing condition data of facade design from some custom house of Batak Toba which is located from three different villages namely Tomok Village, Huta Siallagan and Huta Bolon. Data analysis in this qualitative research is to search and arrange systematically data obtained from the results of field notes and documentation by organizing into categories, describing in units, synthesizing, arranging into patterns and making conclusions.
\end{abstract}

\section{Keywords : Façade, Typology of Batak Traditional House}

\begin{abstract}
Abstrak
Rumah adat Batak Toba adalah salah satu peninggalan tradisi suku bangsa batak yang hingga kini masih banyak meninggalkan nilai-nilai filsafat dan keindahan serta menimbulkan sebuah gambaran alam yang dianggap memiliki jiwa. Rumah adat batak merupakan bangunan rumah yang mencirikan atau khas bangunan dari suku batak yang melambangkan kebudayaan dan ciri khas masyarakat batak. Pembahasan dalam penelitian ini mengenai tipologi fasad bangunan rumah tradisional Batak Toba di Desa Tomok, Huta Bolon dan Huta Siallagan. Tipologi fasad yang dibahas pada penelitian ini adalah tampak depan, penggunaan bahan, dimensi, penggunaan warna, penempatan pintu dan jendela rumah adat tradisional Batak Toba di Samosir. Metode penelitian yang digunakan dalam penelitian ini adalah secara kualitatif, yaitu mendiskripsikan data kondisi eksisting desain fasad dari beberapa rumah adat Batak Toba yang berlokasikan dari tiga desa yang berbeda yaitu Desa Tomok, Huta Siallagan dan Huta Bolon. Analisis data dalam penelitian kualitatif ini adalah mencari dan menyusun secara sistematis data yang diperoleh dari hasil catatan dilapangan dan dokumentasi dengan cara mengorganisasikan kedalam kategori, menjabarkan dalam unit-unit, melakukan sintesa, menyusun kedalam pola dan membuat kesimpulan.
\end{abstract}

\section{Kata Kunci : Fasad, Tipologi Rumah Adat Batak}

\section{Pendahuluan}

Fasad merupakan tampilan yang mencerminkan citra dan ekspresi dari seluruh bagian bangunan, bahkan bisa menjadi jiwa bangunan. Fasad suatu bangunan tidak hanya memenuhi suatu keperluan dibaliknya. Namun dapat mengungkapkan arti, fungsi dan tingkat kemajuan kebudayaan serta sebagai bukti sejarah pada saat bangunan tersebut dibangun. Komposisi fasad harus lebih mempertim-bangkan kebutuhan-kebutuhan fungsional se-perti pintu, jendela, tekstur, bahan-bahan yang digunakan, pelindung matahari dan atap, juga menyangkut struktur.

Rumah adat Batak Toba adalah salah satu peninggalan tradisi suku Batak yang sampai saat ini masih banyak meninggalkan nilai-nilai filsafat dan keindahan. Rumah adat Batak memiliki konstruksi yang menimbulkan sebuah gambaran alam dan juga dianggap memiliki jiwa. Fasad pada bangunan rumah adat tradisional Batak Toba yang kita jumpai saat ini di Provinsi Sumatera Utara tepatnya di Kabu-paten Samosir memiliki keanekaragaman tersendiri. 
Rumah adat ini terbagi atas dua bagian yaitu jabu parsaktian dan jabu/rumah bolon. Jabu parsaktian merupakan tempat penyimpanan barang, tempat ini juga terkadang dipakai sebagai tempat untuk berbicara terkait dengan hal-hal adat. Jabu bolon adalah rumah keluarga besar, rumah ini tidak memiliki sekat atau kamar sehingga keluarga tinggal dan tidur bersama. Rumah bolon ukurannya lebih besar dibanding dengan rumah persaktian. Selain dari ukuran, perbedaan dari rumah bolon dan rumah persaktian terlihat dari ornamen yang diguna-kan, pintu masuk, jendela dan perletakan tangga masuk.

Berdasarkan pemaparan diatas, maka dilakukan penelitian "Tipologi Fasad Bangu-nan Rumah Tradisional Batak Toba di tiga desa pada Kabupaten Samosir, Sumatera Utara yaitu Huta Bolon, Huta Siallagan dan Desa Tomok. Penelitian ini memberikan informasi terkait tipologi fasad rumah adat tersebut yang mana penjabarannya berupa bentuk, tampak depan, ukuran, material dan warna yang digunakan.

\section{Fasad}

Fasad merupakan elemen arsitektur terpenting yang mampu menyuarakan fungsi dan makna sebuah bangunan. Fasad suatu bangunan tidak hanya memenuhi suatu keperluan dibaliknya. Namun, ia dapat mengungkapkan arti, fungsi dan tingkat kemajuan kebudayaan serta sebagai bukti sejarah pada saat bangunan tersebut dibangun. Komposisi fasad mempertimbangkan kebutuhan-kebutuhan fungsional seperti pintu, jendela, tekstur, bahan-bahan yang digunakan, pelindung matahari dan atap, juga menyangkut struktur. Semua itu dapat diolah, dikombinasikan, tetapi semua pengolahan itu dapat dilakukan secara jelas, nyata, benar, wajar, proporsional, dan tidak berlebihan.

Elemen-elemen fasad merupakan unsur atau bidang dari wajah luar bangunan yang memiliki kegunaan. Ditinjau dari kegunaan, elemen fasad memiliki dua fungsi yaitu :

1. Bagian luar berfungsi sebagai unsur wajah bangunan yang dapat mengungkapkan arti, fungsi dan sebagainya dari bangunan.

2. Bagian dalam berfungsi sebagai sarana untuk memenuhi kebutuhan aktivitas manusia yang terdapat didalam bangunan.

\subsection{Rumah Adat Batak Toba}

Rumah Adat Batak Toba adalah rumah adat dari daerah Sumatera Utara. Rumah ini terbagi atas dua bagian yaitu jabu parsakitan dan jabu bolon. Jabu parsakitan adalah tempat penyimpanan barang, tempat ini juga terkadang dipakai sebagai tempat untuk pembicaraan terkait dengan hal-hal adat. Jabu bolon adalah rumah keluarga besar. Rumah ini tidak memiliki sekat atau kamar sehingga keluarga tinggal dan tidur bersama. Rumah adat Batak Toba juga dikenal sebagai Rumah Bolon.

Rumah Batak Toba mempunyai bahan dasar dari kayu. Menurut kepercayaan masyarakat Batak, rumah ini terbagi ke dalam tiga bagian yang mencerminkan dunia atau dimensi yang berbeda-beda. Bagian pertama yaitu atap rumah yang diyakini mencerminkan dunia para dewa. Bagian kedua yaitu lantai rumah yang diyakini mencerminkan dunia manusia. Bagian yang ketiga adalah bagian bawah rumah atau kolong rumah yang mencerminkan dunia kematian.

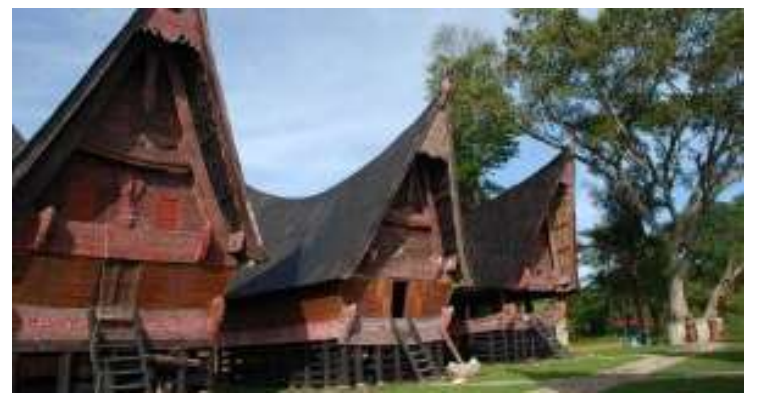

Gambar 1.1 Rumah adat Batak Toba

Sumber : Peneliti, 2017

\subsection{Filosofi Batak Toba}

Pada dasarnya rumah adat bagi masyarakt Batak didirikan bukan hanya untuk berteduh atau tempat tinggal, namun darat dengan nilai filosofi yang merupakan pedoman hidup. Ada beragam nilai-nilai luhur yang ada pada rumah adat tradisional tersebut. Nilai tersebut bermakna sebagai pedoman hidup dalam pergaulan 
antar individu. Filosofi lainnya adalah sebagai bentuk cagar budaya yang dapat menjadi sarana pelestarian budaya. Hal ini bertujuan untuk diwariskan pada generasi penerus.

\subsection{Bagian-Bagian Rumah Adat Batak Toba}

Rumah adat Batak Toba pada bagian-bagian lainnya terdapat ornamen-ornamen yang penuh dengan makna dan simbolisme, yang menggambarkan kewibawaan dan kharisma. Ornamen-ornamen tersebut berupa orang yang menarik kerbau melambangkan kehidupan dan semangat kerja, ornament-ornamen perang dan dan sebagainya. Teknik ragam hias terdiri dari dua cara, yaitu dengan teknik ukir teknik lukis. Untuk mengukir digunakan pisau tajam dengan alat pemukulnya (pasak-pasak) dari kayu. Sedangkan teknik lukis bahannya diolah sendiri dari batu-batuan atau pun tanaga yang keras dan arang. Atap rumah terbuat dari ijuk yang terdiri dari tiga lapis. Lapisan pertama disebut tuham-tuham (satu golongan besar dari ijuk, yang disusun mulai dari jabu bona tebalnya $20 \mathrm{~cm}$ dan luasnya $1 \times 1,5 \mathrm{~m}^{2}$ ). Antara tuham yang satu dan dengan tuham lainnya diisi dengan ijuk agar permukaannya menjadi rata. Lapisan kedua, yaitu lalubaknya berupa ijuk yang langsung diambil dari pohon enau dan masih padat, diletakkan lapis ketiga. Setiap lapisan diikat dengan jarum yang terbuat dari bambu dengan jarak $0,5 \mathrm{~m}$.

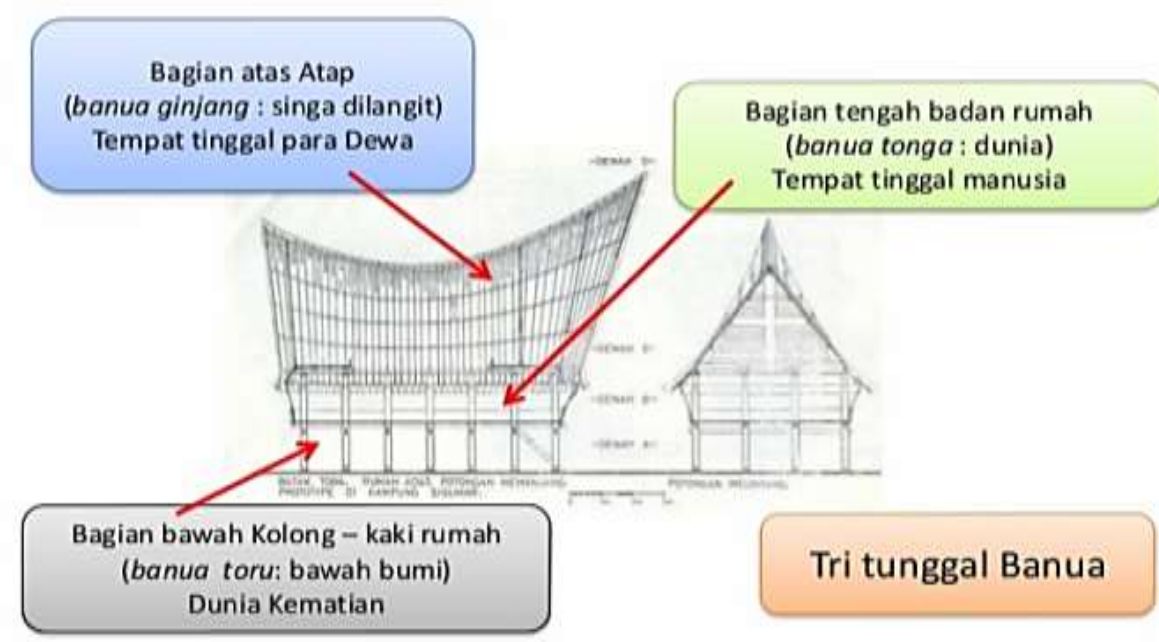

Gambar 1.2 Bagian rumah adat Batak Toba

Sumber : http://www.tobatabo.com/rumah-adat-batak-toba-fungsi-yang-realistis.htm/

Sebelum mendirikan bangunan diadakan musyawarah terlebih dahulu. Hasil musyawarah dikonsultasikan kepada pengetua untuk memohon nasihat atau saran. Setelah diadakan musyawarah, tindakan berikutnya adalah peninjauan tempat. Apabila tempat tersebut memenuhi persyaratan, maka ditandai dengan mare-mare yakni daun pohon enau yang masih muda dan berwarna kuning, yang merupakan pertanda atau pengumuman bagi penduduk disekitarnya bahwa tempat tersebut akan dijadikan bangunan.

\subsection{Tata Ruang Rumah Adat Batak Toba}

Pada bagian dalam rumah (interior) dibangun lantai yang dalam pangertian Batak disebut papan. Agar lantai tersebut kokoh dan tidak goyang maka dibuat galang lantai (halang papan) yang disebut dengan "gulanggulang" dan dapat juga berfungsi untuk memperkokoh bangunan rumah.

Untuk menjaga kebersihan rumah, di bagian tengah agak ke belakang dekat tungku tempat bertanak ada dibuat lobang yang disebut dengan talaga. Semua yang kotor seperti debu, pasir karena lantai disapu keluar melalui lobang tersebut. Karena itu ada falsafah yang mengatakan "Talaga panduduran, lubang-lubang panompasan" yang dapat mengartikan bahwa segala perbuatan kawan yang tercela atau perbuatan yang dapat membuat orang tersinggung harus dapat dilupakan.

Di sebelah depan dibangun ruangan kecil berbentuk panggung (mirip balkon) dan ruangan tersebut dinamai sebagai songkor. Dikala ada pesta bagi yang empunya rumah ruangan tersebut digunakan sebagai tempat "pargonsi" (penabuh gendang Batak) dan ada juga kalanya dapat digunakan sebagai tempat alat-alat pertanian seperti bajak dan cangkul setelah selesai bertanam padi. Setara dengan songkor di sebelah belakang rumah dibangun juga ruangan berbentuk panggung yang disebut "pangabang", dipergunakan untuk tempat 
menyimpan padi, biasanya dimasukkan dalam "bahul-bahul". Bila ukuran tempat padi itu lebih besar disebut dengan "ompon".

Melintang di bagian tengah dibangun "para-para" sebagai tempat ijuk yang kegunaannya untuk menyisip atap rumah jika bocor. Dibawah para para dibuat "parlabian" digunakan tempat rotan dan alat-alat. Karena itu ada fatsafah yang mengatakan "Ijuk di para-para, hotang di parlabian, na bisuk bangkit gabe raja ndang adong be na oto tu pargadisan" yang artinya kira-kira jika manusia yang bijak bestari diangkat menjadi raja maka orang bodoh dan kaum lemah dapat terlindungi karena sudah mendapat perlakuan yang adil dan selalu diayomi.

\section{Metodologi Penelitian}

Metode penelitian yang digunakan dalam penelitian ini adalah secara kualitatif, yaitu mendiskripsikan data kondisi eksisting desain fasad dari beberapa rumah adat Batak Toba yang berlokasikan dari tiga desa yang berbeda, yaitu Desa Tomok, Huta Siallagan dan Huta Bolon. Penelitian kualitatif adalah suatu proses penelitian dan pemahaman yang berdasarkan pada metodologi yang menyelidiki suatu fenomena sosial dan masalah manusia. Pada pendekatan ini, peneliti membuat suatu gambaran kompleks, meneliti dari pandangan langsung, dan melakukan studi pada situasi yang alami. Penelitian kualitatif dilakukan pada kondisi alamiah dan bersifat penemuan.

Sumber data dalam penelitian ini adalah hasil survei dan observasi (foto dan sketsa), wawancara dan studi literatur yang berhubungan dengan analisis kondisi dan fasad arsitektur rumah adat Batak Toba di tiga desa wisata yaitu Desa Tomok, Huta Siallagan dan Huta Bolon.

Analisis data dalam penelitian kualitatif adalah proses mencari dan menyusun secara sistematis data yang diperoleh dari hasil catatan di lapangan dan dokumentasi dengan cara mengorganisasikan kedalam kategori, menjabarkan dalam unit-unit, melakukan sintesa, menyusun kedalam pola dan membuat kesimpulan. Tampak fasad rumah tradisional Batak Toba dianalisa berdasarkan bentuk, skala, ukuran, material, tekstur, serta warna saat dilakukannya survei lapangan. Teknik analisis data yang dilakukan dalam penelitian ini adalah dengan mereduksi data, penyajian data.

\section{Analisa \& Pembahasan}

\subsection{Rumah Adat di Desa Tomok}

Tomok adalah sebuah desa kecil yang terletak dipesisir timur pulau samosir Danau Toba, Samosir sumatera utara. Desa yang sedang berkembang menjadi wisata budaya Tomok yang banyak dikunjungi wisatawan lokal maupun wisatawan asing. Di Huta Tomok terdapat empat (4) Rumah Adat Batak tradisional yang terdapat didalamnya.

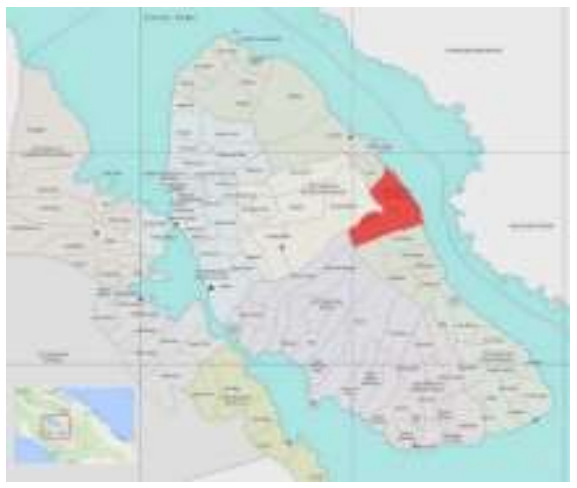

(1)

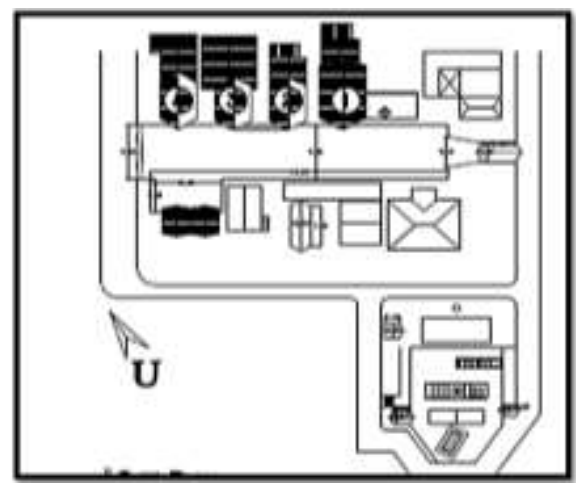

(2)

Gambar 1.3 (1) Peta Desa Tomok ; (2) Pola perkampungan Desa Tomok

Sumber : (1) www.tobasamosirkab.go.id/wilayah ; (2) Peneliti, 2017 


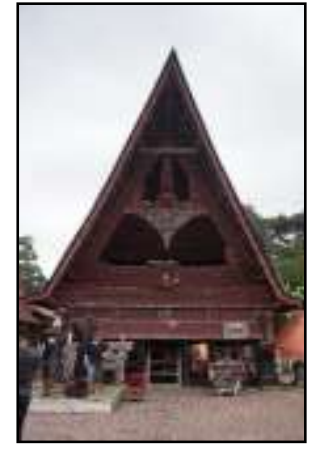

(1)

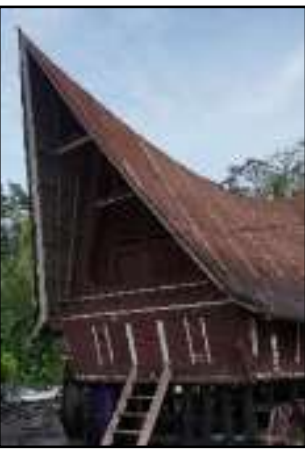

(2)

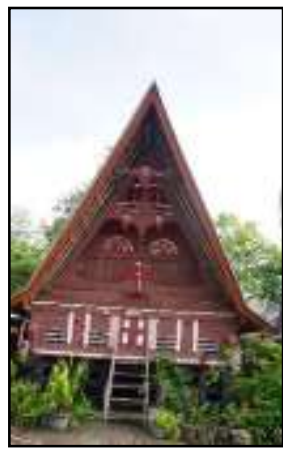

(3)

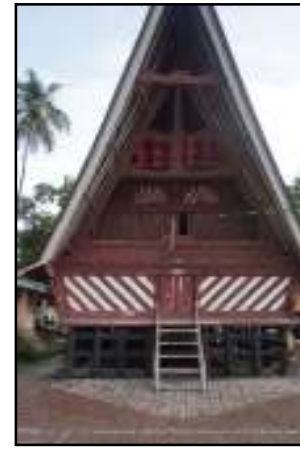

(4)

Gambar 1.4 Fasad rumah adat di Desa Tomok

Sumber : Peneliti, 2017

\subsection{Rumah Adat di Desa Siallagan}

Lokasi Huta Siallagan yaitu di Kecamatan Simanindo, Kabupaten Samosir, Sumatera Utara. Berjarak sekitar $3 \mathrm{~km}$ dari Tuktuk Siadong dan $5 \mathrm{~km}$ dari Tomok. Huta Siallagan memiliki luas wilayah sekitar $2.400 \mathrm{~m}^{2}$ dikelilingi tembok batu tersusun setinggi $1.5 \mathrm{~m}-2 \mathrm{~m}$. Di Huta Siallagan terdapat delapan (8) rumah adat batak tradisional yang terdapat didalamnya.

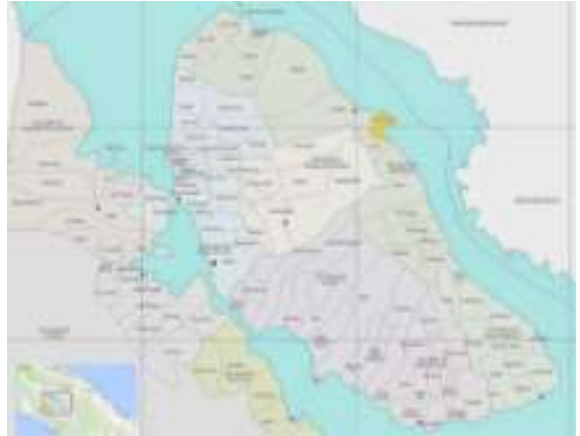

(1)

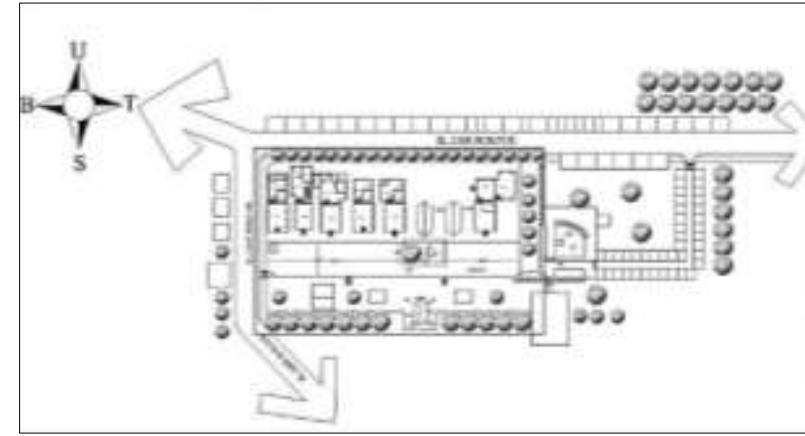

(2)

Gambar 1.5 (1) Peta Huta Siallagan ; (2) Pola perkampungan Huta Siallagan

Sumber : (1) www.tobasamosirkab.go.id/wilayah ; (2) Peneliti, 2017

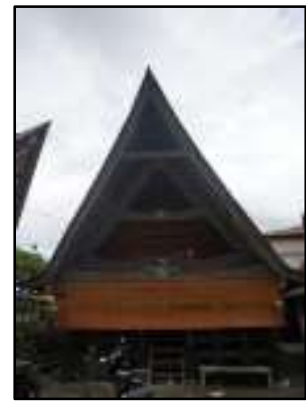

(1)

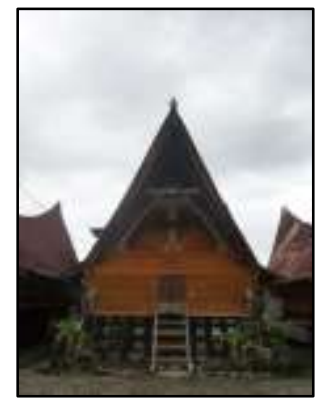

(2)

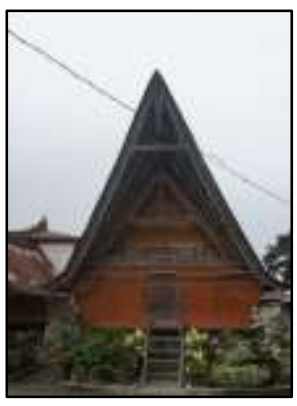

(3)

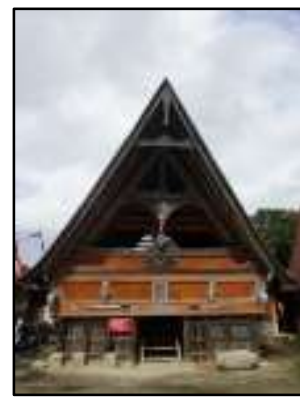

(4) 


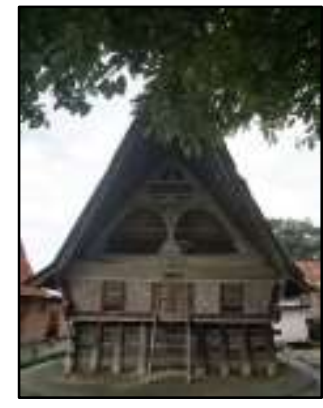

(5)

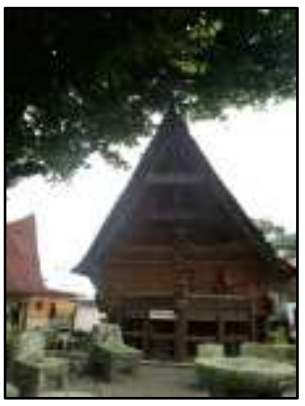

(6)

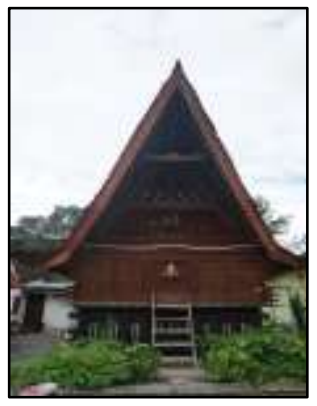

(7)

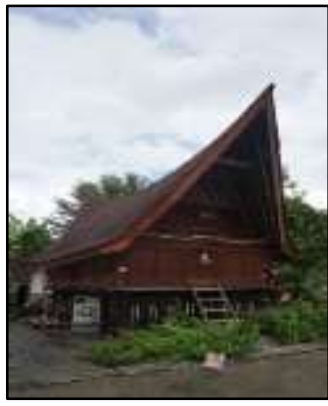

(8)

Gambar 1.6 Fasad rumah adat di Huta Siallagan

Sumber : Peneliti, 2017

\subsection{Rumah Adat di Huta Bolon}

Huta Bolon adalah sebuah desa yang terletak di Simanindo, Kecamatan Simanindo, Kabupaten Samosir, di tepi Danau Toba, Sumatera Utara, Indonesia. Huta Bolon, di Simanindo dapat dicapai dalam waktu 30 menit dengan kapal Ferry dari Parapat ke Tomok dan dari Tomok naik angkutan selama 30 menit. Atau bisa juga dengan kapal kecil dari Tigaras yang langsung menuju ke pelabuhan Simanindo. Di Huta Bolon terdapat tiga (3) rumah adat batak tradisional yang terdapat di dalamnya.

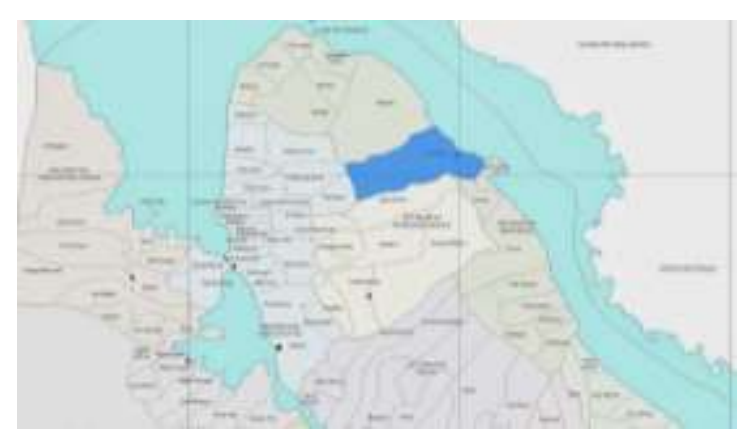

(1)

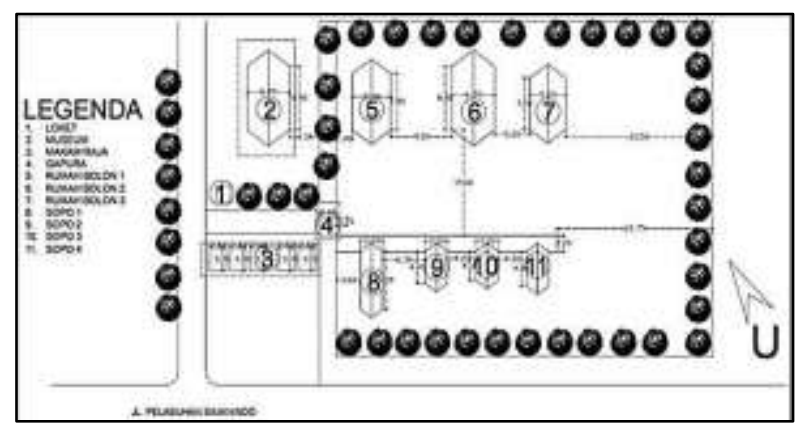

(2)

Gambar 1.7 (1) Peta Huta Siallagan ; (2) Pola perkampungan Huta Siallagan Sumber : (1) www.tobasamosirkab.go.id/wilayah ; (2) Peneliti, 2017

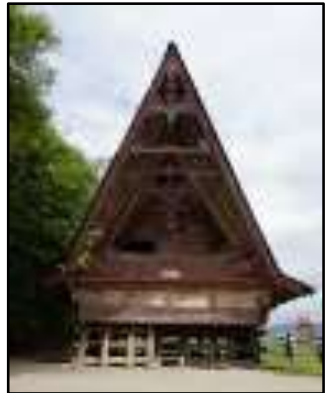

(1)

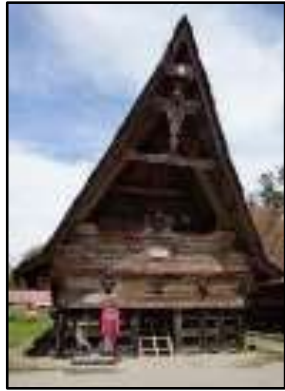

(2)

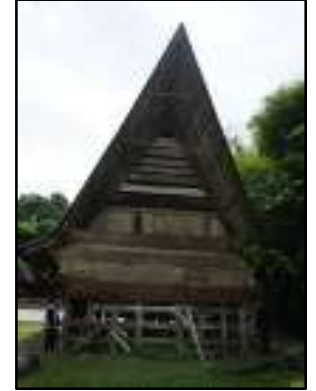

(3)

Gambar 1.8 Fasad rumah adat di Huta Bolon

Sumber : Peneliti, 2018

\subsection{Analisis Penggunaan Bahan}

Dari tiga Huta tersebut yang paling mendekati model dasar dalam penggunaan bahan, yaitu di Huta Bolon yang terdapat pada Rumah Adat 1 dan Rumah adat 2. Sedangkan di Huta Siallagan dan Huta Tomok 
masih terdapat penggunaan bahan yang mengikuti model dasar hanya saja pada penutup atap yang berubah yaitu menggunakan atap seng. Pada bagian kepala Rumah Adat Huta Siallagan, Huta Tomok, dan Huta Bolon penggunaan bahan penutup atap yang digunakan pada model dasar adalah ijuk. Pada bagian badan Rumah Adat Huta Siallagan bahan yang digunakan untuk bagian badan pada model dasar adalah papan dan kayu jati. Pada bagian kaki Rumah Adat Siallagan penggunaan bahan pada model dasar yaitu menggunakan batu pondasi, pada tiang Rumah Adat menggunakan bahan papan, kayu jati dan pada tangga menggunakan papan. Pada bagian kepala Rumah Adat Huta Siallagan, Huta Tomok, dan Huta Bolon penggunaan bahan Rangka atap yang digunakan pada model dasar adalah bambu dan kayu jati.

\subsection{Analisis Penggunaan Warna}

Pada bagian kepala Rumah Adat Huta Siallagan, Huta Tomok dan Huta Bolon warna yang digunakan pada model dasar penutup atap Ijuk berwarna hitam. warna pada bagian badan Rumah Adat Huta Siallagan, Huta Tomok dan Huta Bolon pada model dasar adalah, warna kayu yang masih alami (natural). Warna pada bagian kaki Rumah Adat Huta Siallagan, Huta Tomok, Huta Bolon pada model dasar, bagian tangga warna yang digunakan masih menggunakan warna kayu yang masih alami, warna tiang juga masih menggunakan warna kayu yang asli tanpa ada warna tambahan. Pada bagian kepala Rumah Adat Huta Siallagan, Huta Tomok, dan Huta Bolon penggunaan warna penempatan ornamen pada model dasar adalah merah, putih, hitam, dan papannya menggunakan warna kayu asli.

Dari tiga Huta tersebut yang paling mendekati model dasar dalam penggunaan warna yaitu di Huta Bolon yang terdapat pada Rumah Adat 1 dan Rumah adat 2. Di Huta Siallagan yang mendekati penggunaan warna pada model dasar yaitu terdapat pada Rumah Adat 5. Sedangkan di Huta Tomok tidak ada sama sekali yang mendekati model dasar dalam penggunaan warna, semuanya sudah berubah.

\subsection{Analisis Penggunaan Ornamen}

Ornamen yang terdapat pada bagian kepala Rumah Adat Batak Toba pada model dasar yaitu ornamen:Ture- ture, par hom-hom, tomboman adop- adaop, song-song boltok, halang gordang, sitindangi, sijonggi-jonggi, pusu-pusu ni siantung- antung, ulu paung. Ornamen yang terdapat pada bagian badan Rumah Adat Batak Toba pada model dasar yaitu ornamen: ipon - ipon, si mataniari, desa naualu, jorngom, dan singasinga.

\subsection{Analisis Penggunaan Dimensi}

Pada bagian kepala Rumah Adat Huta Siallagan, Huta Tomok dan Huta Bolon ukuran yang digunakan pada model dasar belum menggunakan ukuran dengan meter, tetapi menggunakan tatacara mengukur dengan depa (dopa), jengkal (jongkal), asta, langkah (langka), sehingga setiap rumah adat cendrung memilik ukuran yang berbeda- beda. Pada bagian badan Rumah Adat Huta Siallagan, Huta Tomok dan Huta Bolon ukuran yang digunakan pada model dasar di setiap Rumah Adat batak toba memiliki ukuran berbeda- beda. Pada bagian kaki Rumah Adat Huta Siallagan, Huta Tomok dan Huta Bolon ukuran yang digunakan pada model dasar di setiap Rumah Adat batak toba di Tiga Huta tersebut memiliki ukuran berbeda- beda.

\subsection{Analisis Penggunaan Tangga, Pintu, dan Jendela}

Pada bagian perletakan tangga model dasar diTiga Huta tersebut yaitu perletakan tangga keluar (masuk dari luar), perletakan tangga didalam (masuk dari kolong). Pada bagian bukaan pintu model dasar diTiga Huta tersebut yaitu bukaan pintu masuk dari arah depan, dan bukaan pintu masuk dari kolong. Pada bagian bukaan jendela model dasar diTiga Huta tersebut yaitu pintu masuk dari arah depan dominan mempunyai bukaan jendela di bagian depan, dan pintu masuk dari kolong dominan tidak memiliki bukaan jendela di bagian depan.

\section{Kesimpulan \& Saran \\ 5.1. Kesimpulan}

Berdasarkan hasil analisis tipologi fasad rumah adat Batak Toba, dapat dilihat kencenderungan yang sama dan kecenderungan yang tidak sama terhadap rumah adat Batak Toba di Desa Tomok, Huta Siallagan dan Huta Bolon. Maka diperoleh hasil pengkajian terdapat fasad rumah adat Batak Toba di Desa Tomok, Huta Siallagan dan Huta Bolon berdasarkan kriterianya, antara lain : 
a.

Penggunaan bahan

Secara keseluruhan untuk penutup atap rumah adat Batak Toba memakai bahan seng namun hanya ada dua rumah adat dari tiga desa tersebut yang memakai bahan atap ijuk. Rangka atap dan penempatan ornamen pada rumah adat Batak Toba di Desa Tomok, Huta Siallagan dan Huta Bolon menggunakan bahan yang sama yaitu bambu, dan papan kayu.

\section{b. Penggunaan warna}

Penggunaan warna pada kepala dan badan di tiga desa tersebut berbeda yaitu yang mencirikhaskan warna tersendiri. Di Huta Siallagan penggunaan warna yang terdapat pada bagian kepala adalah warna coklat muda, dan coklat tua. Di Desa Tomok mecirikhaskan penggunaan warna merah maroon dan di Huta Bolon mencirikhaskan penggunaan warna alami kayu. Penggunaan warna pada bagian kaki di tiga desa terserbut sebagian besar menggunakan warna hitam meskipun ada sebagian warna pada kaki rumah adat tersebut yang masih menggunakan warna dari alami kayu. Penggunaan warna ornamen di Desa Tomok, Huta Siallagan dan Huta Bolon cenderung sama. Desa yang memiliki warna ornamen yang sama yaitu pada Desa Tomok dan Huta Bolon, warna yang digunakan adalah merah, hitam dan putih.Ssedangkan di Huta Siallagan warna ornamen yang digunakan adalah warna hitam, dan putih.

\section{c. Dimensi}

Terdapat perbedaan dimensi diantara tiga desa tersebut. Didalam satu desa juga ada satu rumah yang memiliki dimensi atap cenderung lebih tinggi dari pada rumah yang lainnya. Begitu juga pada badan rumah adat Batak Toba di Huta Bolon dimensi badan cenderung lebih rendah dibanding Huta Siallagan dan Desa Tomok. Dimensi kaki pada tiga desa tersebut cenderung sama namun jumlah kolom yang berbeda.

d. Ornamen

Ornamen yang paling lengkap dari tiga desa tersebut adalah diHuta Bolon. Namun dari tiga desa tersebut hanya ada satu rumah yang lengkap ornamennya. Di Huta Siallagan ornamen yang paling lengkap terdapat pada rumah 4, Huta Tomok terdapat pada rumah 1 dan di Huta Bolon terdapat pada rumah 2.

e. $\quad$ Perletakan tangga, bukaan pintu dan bukaan jendela

Perletakan tangga di tiga desa tersebut sebagian besar menggunakan tangga dengan pintu masuk didepan. Namun ada juga beberapa rumah yang menggunakan tangga kedalam pintu masuk dari kolong. Perletakan tangga kedalam pintu masuk dari kolong dominan tidak memiliki bukaan jendela dibagian depan. Sebagian besar diHhuta Siallagan tidak terdapat bukaan jendela di sisi depan.

Berdasarkan analisis yang dilakukan terhadap fasad rumah adat Batak terdapat beberapa kecenderungan yang sama dan kecenderungan yang berbeda. Kecendrungan yang sama terdapat pada penggunaan bahan, sebagian besar menggunakan atap seng di di Desa Tomok, Huta Siallagan dan Huta Bolon. Juga menggunakan bahan yang sama pada badan, dan kaki. Kecenderungan yang berbeda di tiga desa tersebut adalah dari penggunaan warna hanya pada bagian kaki saja menggunakan warna yang sama.

Di dalam satu desa ada satu rumah yang berbeda dimana rumah ini disebut sebagai rumah bolon yang memiliki ukuran dan dimensi pada kepala bagian atap, dimensi badan dan dimensi bagian kaki, begitu juga dengan kelengkapan ornamen, perletakan tangga, perletakan jendela dan peletakan pintu. Dimana rumah bolon ini dominan memiliki tangga yang masuk dari kolong dan tidak memiliki jendela di bagian depan.

\subsection{Saran}

Berdasarkan hasil analisis dan kesimpulan penelitian di atas, maka penulis merekomendasikan beberapa saran sebagai berikut :

1. Untuk meningkatkan ketelitian dalam melakukan pengambilan data observasi dan pengamatan harus dalam rentang waktu yang cukup dan tidak tergesa-gesa.

2. Kajian tipologi fasad rumah adat Batak Toba ini memerlukan penyempurnaan melalui perubahan berikutnya yang lebih observatif.

Penelitian ini belum komprehensif untuk menyatakan tipologi fasad rumah adat Batak Toba, karena hanya melihat objek lokasi di tiga (3) desa saja, sebaiknya cakupan wilayah penelitian di seluruh rumah adat Batak Toba pada Kabupaten Samosir dan sekitarnya. 


\section{Daftar Pustaka}

Aritonang, Jan. S. 2006. Beberapa Pemikiran Mengenai Teologi Dalihan Natolu. Jakarta : Balai Pustaka.

Bangun, Payung. 1985. Kebudayaan Batak Dalam Masyarakat. Jakarta : Djembatan.

Bogdan, Robert dan Taylor. 1992. Pengantar Metode Penelitian Kualitatif. Surabaya : Usaha Nasional.

Bungin, Burhan. 2012. Analisis Data Penelitian Kualitatif. Jakarta : Raja Grafindo Persada.

Burden, A. 1998. Characterist by Elaboration of Stylistic Details. New York : Princeton Architecture Press.

Depdiknas. 1996. Rumah Adat Batak Toba. Medan : Universitas Nommensen

Irene Debora, eds. 2016. Village Architecture In Sumatera. Vienna, Austria : IVA-ICRA.

Krier, Rob. 2001. Komposisi Arsitektur. Jakarta : Erlangga.

Lippsmeier, G. 1997. Bangunan Tropis. Jakarta : Erlangga.

Moleong, J Lexy, Prof. Dr. 2009. Metode Penelitian Kualitatif. Bandung : PT. Remaja Rosdakaya.

Moleong, J Lexy, Prof. Dr. 2010. Metodologi Penelitian Kualitatif. Bandung : Remaja Rosdakarya.

Moneo, Rafael. 1979. Oppositions Summer on Typology, A Journal for Ideas And Criticism In Architecture. Vol. 13. Massachusetts : The MIT Press.

Sitanggang, Hilderia. 1998. Arsitektur Tradisional Daerah Sumatera Utara. Jakarta : Gramedia Pustaka.

Siti, Nurmala. 2012. Suku Batak Sumatera Utara. Bandung : PT. Remaja Rosdakaya.

Sukada, Budi A. 1998. The Architecture of Early Indepedence. Indonesian Heritage.

Suryakusumo, R. 2006. Pelayanan Publik dan Pengelolaan Infrastruktur Perkotaan. Yogyakarta : Sinergi Publishing dan Magister Administrasi Publik UGM.

Vidler, Anthony. 1976. The Third Typology in Nesbitt. New York : Princeton Architecture Press.

Kamus Besar Bahasa Indonesi (KBBI)

Kamus Bahasa Batak (AKKATEL)

http://www.tobatabo.com/rumah-adat-batak-toba-fungsi-yang-realistis.htm/

http://www.tobasamosirkab.go.id/wilayah 